\title{
Non-State Actors in the Middle East: Towards a New Typology
}

Vitaly V. Naumkin, Vasily A. Kuznetsov

\author{
Vitaly V. Naumkin, PhD in History \\ Full Member of the Russian Academy of Sciences \\ State Academic University for the Humanities, Moscow, Russia \\ Dean of the Faculty of Oriental Studies \\ ORCID: 0000-0001-9644-9862 \\ IstinaResearcherID (IRID): 591858 \\ Scopus Author ID: 6506393597 \\ E-mail: director@ivran.ru \\ Address: 12 Rozhdestvenka Str., Moscow 107031, Russia \\ Vasily A. Kuznetsov, PhD in History \\ State Academic University for the Humanities, Moscow, Russia \\ Faculty of Oriental Studies \\ Associate Professor \\ SPIN-RSCI: 8052-7393 \\ ORCID: 0000-0003-3646-4037 \\ IstinaResearcherID (IRID): 3553785 \\ Scopus AuthorID: 57196044428 \\ E-mail: vasiakuznets@yandex.ru \\ Address: 12 Rozhdestvenka Str., Moscow 107031, Russia
}

This article is part of the research project "Historical and Cultural Traditions and Values in the Context of Global History" (State Assignment \#FZNF-2020-0001 of the RF Ministry of Science and Higher Education) carried out at the State Academic University for the Humanities (GAUGN).

DOI: $10.31278 / 1810-6374-2020-18-4-192-214$ 


\begin{abstract}
The latest developments in world politics have invariably shown the growing role of non-state actors (NSAs) in international affairs. Although this factor has drawn increased attention in both academic discourse and applied research, problems related to NSA typology remain unclarified. The present paper analyzes existing approaches to the categorization of various NSAs operating in the global political arena and proves that the available classifications of NSAs fail to represent present-day political realities, particularly in the Middle East. Proceeding from Phillip Taylor's renowned classification of NSAs, the authors offer a new approach to differentiating NSAs acting in the Middle East, and suggest using such criteria as their relation to the state in terms of functions, state orientation, objectives, and system of management. For reasons of space, the present paper does not discuss the funding of NSAs' operations and the extent to which they resort to violence in their activities.
\end{abstract}

Keywords: non-state actors, the Middle East, regional and global security, relations in the Middle East.

\title{
INTRODUCTION
}

In our previous publication we discussed the need for a new typology of non-state actors with reference to the latest political developments in the Middle East (Naumkin and Kuznetsov, 2020). Published in Russian, the work received a broad response from the Russian-speaking expert community, which prompted us to further elaborate on some of the ideas and share them with the English-speaking audience in order to get more expert opinions.

The profound transformation of the system of international relations in recent years has brought about mixed attitudes in the academia and even made some political analysts characterize today's reality as a "crumbling world" (Barabanov, et al., 2020). Such a pessimistic perception of the present-day developments, although not entirely hopeless, is understandable, especially if one considers exclusively short- or mid-term trends, particularly the multiple crises that states, institutions, ideologies, value systems, and even economies are facing 
nowadays. However, in a longer-term perspective, such perception can be subject to serious critique. In the final analysis, the "crumbling" of the world order is related primarily to the profound re-balancing of the global system and the growing influence of new centers of power on global political processes, specifically BRICS member-states, Middle East actors and, to a certain extent, Southeast Asian countries.

Even though this tendency is far from new and has been discussed by many experts, there is a range of issues that have not yet been fully explored. For instance, there remains a question of primary significance: Will new centers of power, mainly related to Eastern civilizations, seek to adapt themselves to the existing system of international relations or will they try to reshape it to suit their own behavioral patterns in an effort to "Easternize" the fundamental tenets of world politics? In the last case scenario, we may see the realization of the concept of transmodernism advanced by Enrique Dussel, who believes that a solution to the challenges and multiple crises facing humankind today lies in focusing on history and culture of nonWestern states (Dussel, 2012). And while we cannot state categorically that world politics has become predominantly non-Westernized, there are ample grounds to say that there have surfaced some conspicuous non-Western trends. Importantly, these trends manifest themselves more vividly and rapidly in the least regulated and institutionalized areas of international relations, particularly those in which non-state actors have been active.

The role of NSAs in regional and global politics in recent years has been widely discussed in academic publications (Josselin and Wallace, 2001; Andonova, 2017; Moloney and Stone, 2019; Kamel (ed.), 2017; Tsygankov, 2013) and applied research (Calame, 2008; Marrone and Muti, 2019). Apparently, the intensive study of this issue is due to the undeniably increasing influence that NSAs have gained in the international political arena. However, there is a stark paradox: despite the broad use of the term 'non-state actors' and acknowledgement of their relevance to international relations there are few scholars who would provide a clear definition of NSAs and list their essential characteristics. 
Obviously, the lack of understanding of what exactly should be meant by NSA hinders the development of an adequate picture of the modern world. This particularly applies to the Middle East: although the presence of NSAs has been extremely prominent in the region, it has become common to focus exclusively on the activities of armed NSAs while ignoring other types. In a bid to alleviate and streamline the study of global political processes, specifically those underway in the Middle East, we suggest using a comprehensive system for classification of NSAs that would fully reflect the current situation. We believe that our approach to the categorization of NSAs can provide an insight into the changes that have been brought about by the growing impact of NSAs on the developments in the Middle East and other non-Western regions and into how they may influence world politics in the future.

\section{EXISTING CLASSIFICATIONS}

A vast number of researchers exploring the phenomenon of NSAs refer predominantly to Western material in their analysis. However, all authors dealing professionally with the Middle East's problems (and with the Oriental world, in general) realize that the prevalent perception of the substantive nature of NSAs that is common among European and American researchers does not adequately reflect the reality with which we are confronted today. Speculations concerning the similarities and differences between, say, the Daesh/ISIS or the Society of the Muslim Brothers (better known as the Muslim Brotherhood), on the one hand, and large transnational corporations (such as Shell or Exxon Mobil), international non-governmental organizations (such as International Crisis Group) and powerful media corporations (such as $\mathrm{Al}$ Jazeera), on the other hand, constitute a subject for reasonable discourse (Dalacoura, 2001; Josselin and Wallace, 2001, pp. 235248), but it is fairly obvious that such organizations have much more differences than similarities. Moreover, one cannot state with certainty that they differ from nation-states more than they differ from each other. Therefore, it does not seem appropriate to attribute all of them to one and the same category. 
The subject of NSAs began to arouse the interest of international relations experts back in the 1960s after the release of works by Arnold Wolfers (1961; 1962), John Burton (1968), James Rosenau (1969) and, particularly, Joseph Nye and Robert Keohane, whose brief essay entitled Transnational Relations and World Politics (1971) became a milestone in the study of this phenomenon.

Throughout the 1990s and the 2000s, the majority of researchers marked the decreasing role of state actors and the growing influence of non-state actors (Tsygankov, 2013, p.260). However, no streamlined classification has been offered for NSAs participating in international relations. The solution of the problem could partially be facilitated thanks to the ideas formulated by Professor Marina Lebedeva with regard to the re-interpretation of the notion of an 'actor'. She identified several key tendencies in the development of global politics: the dramatic growth of transnationalism; the hybridization of actors and the interweaving of their functions; radical changes in the states that bring about stratification of their resource potential and formation of new resources (educational, humanitarian, etc.) and stratification of the states with regard to the Westphalian system (preWestphalian-Somali, Westphalian and post-Westphalian-the EU); the development of transnationalism (as independent interaction of ministries and departments from various states); the emergence of new phenomena that demonstrate the capacity of a non-state structure or an organization to be an actor; and, finally, the rapid emergence of new actors (Lebedeva, 2016).

Professor Lebedeva's careful analysis, while being very useful for classifying NSAs, unfortunately, fails to adequately describe them. Her line of reasoning only reaffirms earlier known factual evidence, specifically that NSAs exist de facto, that they have been playing an increasingly important role, and that they are becoming more and more diversified.

A close look at various attempts to categorize, at least partially, NSAs shows that the models offered are based on three key ideas.

First, NSAs are basically described "apophatically" in relation to the state and identified as being something that is not a state (Nye 
and Keohane, 1971, p.329). Such an approach serves as a realistic paradigm in which the state is placed at the center of the system of international relations. This approach has practically reigned supreme in world affairs studies. As a result, NSAs have been analyzed not from within, through a profound study of their intrinsic characteristics, but exclusively from their relation to the state.

So, it would make sense to ask the question: Is it possible to produce such a classification of actors currently present in the international arena in which the state would be just one of several potential players, while the classification itself would be based on more robust criteria than those conventionally accepted today? At the same time, it is obvious that the state-centric approach to the NSA categorization stems not only from the academic tradition, but also from the fact that NSAs build their behavioral patterns using the state as a reference point and thereby regard themselves as either something bigger or smaller than the state, or as an alternative to it.

Second, NSAs are construed primarily as parties to the system of international relations, the basic principle of which is drawing a distinct line between domestic and foreign policies.

The logical consequence of these two approaches implies that an NSA is transnational in nature, or that it must operate in at least two countries. Incidentally, Joseph Nye and Robert Keohane argue that transnationalism does mean geocentricism and that most transnational players are linked to one state or another: "The organization becomes geocentric when its top management and its behavioral patterns indicate that it has lost any traction with one or another state" (1971, p.336; Taylor, 1984, p.20).

Insofar as the division of NSAs into state-centric and geocentric can be very productive (we will get back to this below), the basic premise here seems to be flawed. The strict separation of domestic policies from foreign policies virtually means that international relations research should be concerned with the external behavior of actors, rather than the processes taking place on the world scene. In this context, the key question arises: Who exactly must be regarded as an actor? Since the notion of NSA is built on the notion of the state, both should be 
considered "community agents." However, separating the internal from the external does not imply exclusion of domestic political processes from our review. For good reason, given the present-day strong interpenetration of domestic and foreign policies, this approach to NSAs seems to be perfectly rational. Thus, an NSA can be defined as an international player which pursues activities in a single or several states, possesses a certain degree of independence, and is able to interact with other actors, including state and non-state ones.

Third, NSAs have a certain organizational structure and identifiable objectives (Taylor, 1984, pp.23-24). American researchers Gina Ligon and Michael Logan, while dealing exclusively with the phenomenon of violent (armed) non-state actors (VNSA), suggested determining the level of complexity for any organizational structure by considering three criteria: the extent of (1) centralization, (2) formalization and (3) specialization (Ligon and Logan, 2019). However, by focusing on the last category, as we will show below, one can reveal more information about an organization's objectives than by simply observing its structure.

Generally, a high degree of centralization in an organization's decision-making and, consequently, aspirations to build internal hierarchies, are characteristic of more sophisticated systems. However, as the scope of operations begins to grow and centralization of such an organization becomes more diverse, its extended top management tends to claim greater power and authority from its leader, while at the same time delegating responsibility for operational management of its activities to lower levels, which eventually leads to decentralization. Besides, VNSAs, which are organizationally sophisticated, seek to ensure a greater degree of formalization of their activities through the introduction of special regulations, procedures, symbols, etc. (Ligon and Logan, 2019).

In purely theoretical terms, the availability of a developed organizational structure ensures that the player is more likely to attain its goals. Yet the more structurally sophisticated an organization is and the broader the diversity of its operations, the more heterogeneous and even inherently controversial its goals and objectives become. Hence, in most complicated scenarios, which essentially involve nation-states, the issue of defining their goals of existence cannot be resolved unilaterally. 
Using the principles highlighted above, various authors have suggested quite similar classifications of NSAs. Further on in our study we will largely rely on the classification described by Philip Taylor back in the 1980s. Essentially, it is based on the division of all NSAs into intergovernmental and non-governmental categories, that is, those which pursue their activities within one region or on a global scale and those which specialize in one or another field.

Realizing that Philip Taylor's book came out almost 40 years ago (a very impressive timespan indeed) and has raised much argument calling into question practically every tenet underlying his conception, we have made substantial adjustments to his theory and added more criteria for categorizing NSAs.

Table 1. Classification of Non-State Actors by Phillip Taylor (1984, p.22)

\begin{tabular}{|c|c|c|c|c|c|}
\hline & & Economy & Security & Politics & $\begin{array}{l}\text { Culture/ } \\
\text { Ideology }\end{array}$ \\
\hline \multirow[t]{2}{*}{$\begin{array}{l}\text { International } \\
\text { Governmental } \\
\text { Organizations }\end{array}$} & $\begin{array}{l}\text { Supra- } \\
\text { Regional }\end{array}$ & $\begin{array}{l}\text { OPEC } \\
\text { GATT } \\
\text { OECD } \\
\text { CIPEC }\end{array}$ & $\begin{array}{l}\text { NATO } \\
\text { UN SC }\end{array}$ & & Islamic Council \\
\hline & Regional & $\begin{array}{l}\text { ASEAN } \\
\text { Andean } \\
\text { Community } \\
\text { ECOWAS }\end{array}$ & $\begin{array}{l}\text { Baghdad } \\
\text { Pact } \\
\text { Pacific } \\
\text { Security Pact } \\
\text { (ANZUS) }\end{array}$ & $\begin{array}{l}\text { African Union } \\
\text { (AU) } \\
\text { Council } \\
\text { of Europe }\end{array}$ & $\begin{array}{l}\text { LAS } \\
\text { Nordic Council }\end{array}$ \\
\hline \multirow[t]{2}{*}{$\begin{array}{l}\text { International } \\
\text { Non- } \\
\text { Governmental } \\
\text { Organizations }\end{array}$} & $\begin{array}{l}\text { Supra- } \\
\text { Regional }\end{array}$ & $\begin{array}{l}\text { Shell } \\
\text { IBM } \\
\text { GM } \\
\text { Exxon }\end{array}$ & $\begin{array}{l}\text { Int. Labor } \\
\text { Unions }\end{array}$ & $\begin{array}{l}\text { International } \\
\text { Labor } \\
\text { Organization } \\
\text { (ILO) }\end{array}$ & $\begin{array}{l}\text { Amnesty } \\
\text { International } \\
\text { IOC } \\
\text { International } \\
\text { Helsinki } \\
\text { Federation } \\
\text { for Human Rights }\end{array}$ \\
\hline & Regional & $\begin{array}{l}\text { Union } \\
\text { of Arab } \\
\text { Chambers }\end{array}$ & $\begin{array}{l}\text { Jewish } \\
\text { Defense } \\
\text { League (JDL) } \\
\text { IRA } \\
\text { Ulster } \\
\text { Protestant } \\
\text { Vanguard }\end{array}$ & $\begin{array}{l}\text { Palestinian } \\
\text { Liberation } \\
\text { Organization } \\
\text { (PLO) }\end{array}$ & $\begin{array}{l}\text { Ebo } \\
\text { Basques } \\
\text { Kurds } \\
\text { Azerbaijanis } \\
\text { Pashtuns }\end{array}$ \\
\hline
\end{tabular}




\section{TYPOLOGY OF NON-STATE ACTORS OPERATING IN THE MIDDLE EAST}

We presume that an NSA typology should be based on four key criteria.

\section{Criterion 1: Correlation with the state in terms of the functions performed}

Since all NSAs are construed as something that is not a state, the question arises: How do these entities correlate with states? It is reasonable to believe that such an entity can be something bigger than a state, in other words, this can be a supra-state actor (SSA); some kind of an alternative to the state, i.e. an alter-state actor (ASA); or something smaller than the state, i.e. a sub-state actor (SSA2). While being independent, they can maintain partnership, neutral or hostile relations with the state.

Consequently, the SSA2s can be subdivided into the supranational (SN), intergovernmental (IGO), non-governmental (INGO), or antisystem (AS) organizations.

The only example of the first subgroup found in international practice is the European Union whose integration experience remains unmatched. In the Middle East, the Cooperation Council for the Arab States of the Gulf (GCC) has been moving towards adopting such experience and, as a result, the Arab leaders have conceived the idea of turning the Council into a Union (Hammond, 2012). At the declaratory level, the idea has survived until now (Al Khalifa, 2019), but its practical implementation is highly unlikely in the near future. Apart from the problems in the relations among the monarchies of the Gulf, the key obstacle is the high degree of personification of power and sovereignty in the GCC member-states (and, similarly, in the Arab states in general) (McMillan, 2013, pp.4-5), as well as their unwillingness to make any compromise. Also, the well-known failures in the EU's performance reduce motivation to go along this path.

Traditionally, intergovernmental actors make up a very sizeable group of players within the system of international relations. This category incorporates the bulk of international organizations whose membership includes nation-states. If theoretically subnational entities 
possess a certain degree of independence and elements of sovereignty, then IGOs are virtually entirely dependent on their member-states. Nevertheless, in some circumstances, in the UN for example, they can be regarded as independent players in world politics. In addition to the GCC, there are other actors of this type operating in the Middle East: the League of Arab States (LAS), the Arab Maghreb Union (AMU), and the Organization of Islamic Cooperation (OIC) that comprises a vast majority of states in the Middle East, even though it cannot be recognized as a regional organization. The profound dependence of all these entities on the regional nation-states, whose relations are characterized by numerous and sometimes grave conflicts, has rendered them virtually ineffective (remarkably, the last AMU summit was convened back in 1994).

A somewhat greater role can be assumed by non-governmental entities at the supranational level. These are international nongovernmental organizations (INGOs), various transnational corporations (TNCs), international humanitarian organizations, and expert panels.

Finally, specific to the Middle East are supranational anti-system players which seek to fundamentally destroy the existing world order and regional structures. A graphic example is Al Qaeda (until 2001) and Daesh/ISIS (banned in Russia), if the latter is viewed not as a territorial entity, but as a specific project of global magnitude.

Notwithstanding the fact that examples of supranational actors (SNAs) almost of all types can be found in the Middle East, it is obvious that their role in both regional and global politics remains marginal.

The situation is not quite the same with the alter-state actors (ASAs), that is, players which position themselves as an alternative to existing states. Tentatively, they can be subdivided into three subcategories.

The first subcategory includes proto-state entities ( $\mathrm{PrS})$, represented by liberation or secessionist movements in control of certain territories with a varying degree of effectiveness. The most conspicuous examples are the Palestine Liberation Organization (PLO) operating on the west bank of the River Jordan, and only partially recognized by the international community; HAMAS in the Gaza sector; Iraqi Kurdistan; 
and the "Republic" of Rojava in northern Syria that acted during the period of its de facto independence (Radpey, 2016; Palani, et al., 2020).

The second subcategory consists of revolutionary organizations seeking to change their country's political regime or to drastically overhaul the political system of one or another state. These are national liberation movements of the late colonial era, which have almost vanished from the Middle East political scene but which formerly constituted a force that shaped its image: various organizations of Arab nationalists, organizations that act under Islamic slogans, underground communist parties, and ultra-leftist movements.

Finally, the third subcategory refers to anti-system movements which fight not against the system of international relations as such, but rather against the very concept of nation-state. This third category includes identifiable territorial incarnations of ISIS, coordination committees of Kabilya villages (Coordination of Arouch, Dairas and Communes-CADC) (Tilleli, 2003), etc.

As far as sub-state actors (SSA2s) are concerned, in contrast to supra-state actors (SSAs) and alter-state actors (ASAs), they do not oppose themselves to existing states, and yet, while recognizing their existence, SSA2s operate as if in the shadow of states. Just like nonstate agents of the previous category, SSA2s are not homogeneous and therefore can be subdivided into two groups.

The first group is comprised of transnational entities operating in different countries or closely interrelated organizations operating in separate states. Examples of SSA2s are the Society of Muslim Brothers, the Hezbollah party in Lebanon, the Ansarullah movement in Yemen, and the Hayat Tahrir al-Sham (banned in Russia, formerly known as Jabhat al-Nusra and regarded as the Syrian affiliate of Al Qaeda). However, various human rights advocacies, humanitarian and expert organizations operating in separate countries can also be included in this category.

The second group of SSA2s includes local associations that do not have any global or regional agenda but that de facto operate independently from a concrete state or in defiance of a state, while at the same time being connected to other similar organizations or 
states. Among them are multiple Shiite, Sunni, and Christian militia formations in Iraq, Syria, and Lebanon (Ucko, 2008; Pack, 2019) and some criminal groups.

By classifying various NSAs according to the suggested principle, we can uncover several important aspects of regional politics. Specifically, this approach vividly shows that the degree of NSAs' influence on regional and global agendas by NSAs operating in the Middle East is in inverse proportion to the degree to which they are tied to a given state. That is, SSAs have the least effect on Middle East developments, while SSA2s do not influence them to the utmost extent. Consequently, there is a difference in the degree of NSAs' dependence on external forceson the states and other NSAs. To illustrate, the HAMAS movement in Gaza is strongly dependent in terms of finance as it receives lavish support from Qatar, while in the economic and security terms its main benefactor is Egypt, which controls the border with Israel that has imposed a blockade on the Gaza Strip for an indefinite period of time.

Evidently, some players can be reasonably ascribed to different categories. This can be explained by the lack of available information and the difference in interpreting their nature and objectives. Such is the situation with the abovementioned Hayat Tahrir al-Sham in Syria. While the majority of experts consider this organization to be an Al Qaeda affiliate, others tend to regard it as a local Syrian force, which, due to a random string of circumstances, has declared that it belongs to the terrorist organization (Al-Tamimi, 2018). Also, some organizations can have more than one identity. For example, the Daesh/ ISIS is regarded as a global force and as a fusion of territorial players, each having its own strategy.

Finally, one more reason for introducing additional criteria for categorizing NSAs is that the same groups can embrace completely different entities, for example, terrorist and human rights organizations.

\section{Criterion 2: State-Centric vs Geocentric Actors}

As has been mentioned above, Joseph Nye and Robert Keohane came up with the idea of dividing NSAs into state-centric (SC) and geocentric (GC) categories. This division might be slightly improved 
by subdividing the state-centric group of actors into several subcategories.

The first subcategory includes non-state entities that act in the interests of this or that state (not necessarily in its territory), maintain close interaction with state institutions and, generally, build their behavioral strategies proceeding upon the fundamental guidelines of state centrism. This category embraces all sorts of proxies, both armed and non-armed.

The second subcategory is comprised of organizations which, although acting in their own interests, closely interact with identifiable governments, thereby trying to fit in-to a greater or lesser extent-the available system of political and economic relations. A vivid example of such organizations is transnational corporations. In the not-so-distant past analysts throughout the world were predominantly convinced that the largest TNCs were effectively independent from national governments. One of the most conspicuous cases was illustrated by Exxon Mobil, which was believed to be able to change the governments in some African states, if such necessity were to arise (Panić, 1998). Meanwhile, the latest events have proved the opposite: in the continuing fierce fight against sanctions, even the largest corporations have to sacrifice part of their financial and economic interests in order to show loyalty to their national governments and act in support of the latter's policies. Presumably, the ongoing intensive discourse on state sovereignty in connection with the COVID-19 pandemic will strengthen this tendency in the short-term perspective (Krastev, 2020).

Finally, those players which have retained their state-centric behavioral pattern, even though not associated with any particular government or opposed to it, can be ascribed to the category of statecentric actors (SC). Some of them, for instance revolutionary and liberation movements, can treat national governments as their enemies and seek to overthrow them, while others, some proto-state actors (PrS), would want to replace them; and still others, including local criminal elements, even if they have transboundary connections, tend to act in the recesses of public life and beyond the control of the state. 
However, all of them, regardless of their diversity, are defined exclusively in connection with their relationship with a certain state, the mere existence of which gives them a raison dêtre.

In comparison with this kind of NSAs, the list of geocentric (GC) actors is much shorter. Only entities that have completely broken away from the state-centrist model and that have become the first adherents of globalism can be associated with this group. Some of them, such as Al Qaeda and Daesh/ISIS, have tried to destroy the world system in a bid to create something entirely new on its debris. Others, such as transSahara criminal groups, engaged in contraband trade (cigarettes, fuel etc.), kidnapping and human trafficking, operate locally and do not seek to implement any great change. They identify themselves not with a state but with a specific territory, in this case the Sahara Desert. Finally, the third category, on the contrary, embraces global mainstream supporters who juxtapose loyalty to an individual state with loyalty to the very idea of globalization. This category includes multiple international nongovernmental organizations, such as the International Crisis Group (ICG) or the Humanitarian Dialogue (HD) Center.

\section{Criterion 3: The Purpose of Activities (Universal or Specialized)}

When Phillip Taylor devised his classification, he chose the field of activity as a key criterion for non-state actors, emphasizing their further division into those that specialize in economic matters, security, politics, culture, and ideology. By dividing NSAs accordingly, the objectives sought by one or another organization can be discerned more clearly. The problem associated with this approach is that the list of designated fields of specialization may be arbitrary. Today, almost forty years after the publication of Phillip Taylor's work, we find it reasonable to add other fields of specialization to his list, such as environmental protection, civil rights, information, and expert review. It is likely that in the future the list will be further expanded by additional categories.

Furthermore, some of the categories may be subject to revision. For instance, the recent introduction of the concept of regional security into world politics has provided a common denominator for a huge 
number of organizations whose activities were previously not related to this field. Remarkably, the Russian Concept of Security in the Persian Gulf Region (RF Ministry of Foreign Affairs, 2019) places regional security in the economic and energy sphere and is supposed to be handled by a dedicated organization in the future. Moreover, the paper addresses issues concerning the regulation of migration flows and humanitarian cooperation. So, many NSAs are simultaneously engaged in several spheres of activity, and some of them have indeed become universally oriented.

Thus, as the scope of an organization's operations grows, its original objectives become less apparent. This can be vividly illustrated by the activities of Hezbollah, which emerged as a military-political group but has grown into a political party, one that is concurrently and vigorously engaged in social, business and media pursuits and, as some experts believe, criminal operations as well (Levitt, 2013). It is impossible to tell which of Hezbollah's diverse pursuits is its core activity today, and which of them are of minor significance.

If we compare the division of actors according to the criterion that focuses on the goals of their operations and differentiate them in accordance with their relation to the state, we can see a certain correlation.

Basically, any entity that replaces or seeks to replace a nation-state or a concrete political system is (actually or potentially) universal. Consequently, supranational organizations, proto-state entities and anti-system players that have both supra-state and alter-state varieties (and these may include sub-state actors, transnational and local players), are all part of the universal category of NSAs.

A major aspect of state-centric actors, at least those pertaining to the first two subgroups (state-dependent and state's partners-see Table 2), are specialized entities. Those among them that are closely linked to a nation-state are more often than not oriented towards military-political or cultural and ideological activities, while those that largely maintain partnership relations with the state are more focused on economic issues, social or humanitarian operations. Universalism, in a varying degree, can be a characteristic feature (but not necessarily) 
either of geocentric actors or those entities that have retained only ideological orientation towards the state.

\section{Criterion 4. Management System}

As can be seen from a review of NSAs' activities in terms of their objectives, the lower the level of an actor the greater the difficulty we experience in determining the degree of universalism they exhibit. This is largely related to the specific aspects of their management, namely, the extent of its formalization and centralization. For it is evident that large organizations are characterized by a higher degree of formalization of their activities than smaller ones, whereas multipurpose or universal organizations are distinctly marked by a mature system of decentralization.

Structures seeking to replace the state (by usurping its functions in a concrete territory or in individual domains of public life) are doomed to replicate the state's experience and create identical governance mechanisms. In this respect, the practices of Islamic political movements are of particular interest as alongside their expansion and diversification of their activities, a tangibly greater role is ascribed to collective management bodies-Shura councils. More specifically, we refer to the Muslim Brotherhood, Al-Nahda in Tunisia, and a few other parties and movements. In some cases, this circumstance may lead to internal conflicts between the leaders of such organizations and their entourage who are prone to claim more and more power over time. This can occur even when an NSA has in principle dismissed the very idea of a nation-state. A vivid example is Daesh/ISIS which has undertaken to set up analogous ministries and departments, and to upgrade the system of regional executive authorities (Ligon, et al., 2014).

NSAs which operate locally and do not need to build an open interaction model with the state are either not focused on formalizing their activities (while relying on customs, traditions or personal connections), or are totally unwilling to reveal the details of their internal organizational structure.

However, there is a certain share of NSAs which are engaged in extremely high-magnitude and well-diversified operations, yet which 
at the same time manage to avoid any serious formalization of their activities. The Hizmet movement (supporters of Fethullah Gulen, banned in Russia) is one such organization. Due to a thoroughly developed ideology and the remaining threat from the outside such NSAs have maintained their image and a high level of consolidation.

\section{A Redundant Criterion. Operational Practice}

A great many experts on the Middle East focus their attention on the analysis of the activities of the so-called violent (armed) non-state actors (VNSAs) as opposed to the non-violent actors: "In general, non-state actors (NSAs) can be broken down into two large categories: non-violent and violent. Those attributed to the first category are the greatest in number" (Elbahy, 2019, p.45). This idea can be traced back to notable works that explore, inter alia, VNSAs, and are written by a renowned expert on the Middle East, Irina Zvyagelskaya. She differentiates between two basic groups of NSAs: "The first group is comprised of movements and organizations whose formation and strengthening are directly linked with the weaknesses of the state which is incapable of providing security for its citizens and fulfilling its social obligations, or is completely disintegrated. Thus, the population is confronted with the necessity to take up arms in order to survive in such complicated circumstances and seeks to get affiliated with any, even the most radical, forces. By getting associated with such forces, people regain hope that they will be protected. The emergence of the second group of non-state actors is related to the state's non-availability, which occurs when separate organizations, capable of devising an attractive agenda and ensuring a high degree of mobilization, try to perform the state's functions" (Zvyagelskaya, 2019, p.161).

Some researchers have offered a more detailed classification of VNSAs. Phil Williams, for one, singles out warlords, militia, paramilitary, insurgents, terrorist formations, criminal and youth gangs (Williams, 2008).

While the identification of the VNSAs as a single category conforms to the deep-seated tradition and can be useful for specific research, its methodological value should not be overestimated. 
Table 2. Classification of Non-State Actors

\begin{tabular}{|c|c|c|c|c|c|c|c|c|}
\hline & \multicolumn{3}{|c|}{$\begin{array}{l}\text { Relation to the state } \\
\text { in terms of functions }\end{array}$} & \multicolumn{2}{|c|}{ State orientation } & \multirow{2}{*}{\begin{tabular}{|l}
$\begin{array}{l}\text { Purpose } \\
\text { of } \\
\text { activities }\end{array}$ \\
U/S
\end{tabular}} & \multirow{2}{*}{\begin{tabular}{|l} 
Formal- \\
ization of \\
manage- \\
ment \\
F/NF
\end{tabular}} & \multirow{2}{*}{\begin{tabular}{|l}
$\begin{array}{l}\text { Central- } \\
\text { ization }\end{array}$ \\
$\mathrm{NC/C/}$ \\
$\mathrm{DCl}$ \\
Network
\end{tabular}} \\
\hline & $\begin{array}{l}\text { SSA } \\
\text { (SN/IGO/ } \\
\text { INGO/ } \\
\text { AS) }\end{array}$ & $\begin{array}{l}\text { ASA } \\
\text { (PrS/ } \\
\text { Rev/ } \\
\text { AS2) }\end{array}$ & $\begin{array}{l}\text { SSA2 } \\
\text { (TN/ } \\
\text { LOC) }\end{array}$ & $\begin{array}{l}\mathrm{SC} \\
\text { (SD/SP/ } \\
\text { SOr) }\end{array}$ & $\begin{array}{l}\text { GC } \\
\text { (AS3/Sh/ } \\
\text { Sys) }\end{array}$ & & & \\
\hline LAS & IGO & & & SD & & U & $F$ & DC \\
\hline ISIS & AS & AS2 & & & AS & U & $F$ & \begin{tabular}{|l|} 
DC/ \\
Network
\end{tabular} \\
\hline LNA & & & LOC & SD/SOr & & $\begin{array}{l}\text { S } \\
\text { (Military- } \\
\text { Political) }\end{array}$ & $F$ & C \\
\hline $\begin{array}{l}\text { Muslim } \\
\text { Brother- } \\
\text { hood }\end{array}$ & & & TN & SP/SOr & & U & $F$ & $\begin{array}{l}\text { DC/ } \\
\text { Network }\end{array}$ \\
\hline HAMAS & & AS2 & & SOr & & U & $F$ & C \\
\hline Hizballah & & & LOC & $\mathrm{SP}$ & & U & $\mathrm{F}$ & \\
\hline $\begin{array}{l}\text { Hizbal- } \\
\text { lah and } \\
\text { other } \\
\text { Shi'a } \\
\text { move- } \\
\text { ments }\end{array}$ & & & TN & SP & & U & $F$ & Network \\
\hline $\mathrm{OIC}$ & IGO & & & $\mathrm{Dd}$ & & U & $F$ & DC \\
\hline
\end{tabular}

\section{Legend:}

SSA - Supra-State Actors:

$\mathrm{SN}$ - Supra-National

IGO - Intergovernmental Organization

INGO - International Non-Governmental

Organization

AS - Anti-System

ASA - Alter-State Actors:

PrS - Proto-State

Rev - Revolutionary

AS2 - Anti-System

\section{SSA2 - Substate Actors}

TN - Transnational

Loc-Local

SC - State-Centric

SD - State-Depended

SP - State Partners

SOr - State-Oriented
GC - Geocentric

AS3 - Anti-System

Sh - State-Shadow

Purpose of Activities

U - Universal

S - Specialized

Formalization of Management:

F - Formalized

NF - Non-Formalized

\section{Centralization of Management}

NC - Non-Centralized

C - Centralized

DC - Decentralized

Network 
Firstly, the use of violence by one or another NSA is a long-established customary practice, deeply rooted in international relations and, therefore, not exclusive to organizations that fall under the category of VNSAs. History provides a lot of examples: the activities pursued by Catholic Orders in medieval times, the ventures of East- and WestIndia companies in the modern age, the use of private armies by contemporary transnational corporations working in zones of conflict, and the actions undertaken by practically any national movement.

Secondly, no VNSA intends to use violence for the sake of violence-any VNSA seeks to reach specific political, economic, social, religious, humanitarian or other goals. Accordingly, they are grouped into separate categories.

Thirdly, the greater share of categories that a VNSA falls into is not surprising-almost all players involved in fomenting regional relations in the Middle East periodically accuse each other of terrorist activities.

In a broader perspective, it may be worthwhile dividing NSAs not into violent and non-violent categories, but rather into those which do not claim the right to perform basic functions from other actors (primarily, from the state), including a monopoly on violence, and those which claim such a right. For if they do, we need to specify which particular functions we mean. However, this will get us back to the same parameters that were discussed above and that are linked to the relationship between an NSA and the state, as well as to the specialized focus of its operations.

Our classification of NSAs operating in the Middle East is summarized in Table 2 which groups together various parameters in a structured fashion.

We believe that the system of classification presented in this article can open a new perspective on the problem of non-state actors. Our approach is not limited to the framework of violent NSAs, which is typically employed in the Middle East research, as it offers a more comprehensive methodology for studying the phenomenon. As has been shown above, this approach to categorizing NSAs assumes critical 
relevance when many NSAs (HAMAS, the Muslim Brotherhood, etc.) conflate-through their activities and identities-completely different political and social functionalities, from armed groups to civil movements or political parties, while retaining commitment to achieving their religious and political goals. The multidisciplinary analysis offered in the article provides substantiation for the internal division within those organizations, shows the sources of their flexible structure, and defines the position they have obtained in world affairs in relation to the states and other NSAs.

We believe that our classification of NSAs allows all of us to go beyond the common perception of the Middle East as a perpetual battlefield left to the discretion of warring armed NGAs. We argue that it is not the adherence to violent practices that should make the essential analytical benchmark for categorizing non-state actors, but a whole set of relevant characteristics, such as their relation to the state, the purpose of their activity and the system of management. With this advanced set of criteria we can create a single analytical model for stratification of the entirety of non-state actors in the system of international relations - from tribal associations and religious groups to transnational corporations and non-governmental organizationsthat would appreciate their specificity.

Naturally, the classification of non-state actors produced on the basis of the comprehensive approach offered herein should not be seen in absolute terms. Yet we believe that it is flexible enough to be easily adapted to suit the specificity of other regions or adjusted to be in accord with new empirical data pertaining to the Middle East.

\section{References}

Andonova, L.B., 2017. Governance Entrepreneurs: International Organizations and the Rise of Global Public-Private Partnerships. Cambridge: Cambridge University Press.

Barabanov, O., Bordachev, T., Lissovolik, Y., Sushentsov, A. and Timofeev, I., 2020. Staying Sane in a Crumbling World. Valdai Discussion Club Report [online]. Available at: <valdaiclub.com/files/30052/> [Accessed 30 March 2020]. 
Burton, J.W., 1968. Systems, States, Diplomacy and Rules. Cambridge: Cambridge University Press.

Calame, P., 2008. Non-State Actors and World Governance. [online]. Available at: $<$ world-governance.org/en/non-state-actors-and-world-governance $>$ [Accessed 30 March 2020]

Dalacoura, K., 2001. Islamist Movements as Non-State Actors and Their Relevance to International Relations. In: Josselin, D. and Wallace, W. (eds.). Non-State Actors in World Politics. London: Palgrave Macmillan, pp.235-248.

Dussel, E. D., 2012. Transmodernity and Interculturality: An Interpretation from the Perspective of Philosophy of Liberation. Transmodernity: Journal of Peripheral Cultural Production of the Luso-Hispanic World, 2012, 1(3), pp.2859. Available at: <https://escholarship.org/uc/item/6591j76r > [Accessed 30 November 2020].

Elbahy, R., 2019. Deterring Violent Non-State Actors: Dilemmas and Implications. Journal of Humanities and Applied Social Sciences, 1(1), pp.43-54.

Hammond, A., 2012. Analysis: Saudi Gulf Union Plan Stumbles as Wary Leaders Seek Detail. [online]. Available at: <www.reuters.com/article/us-gulf-union/ analysis-saudi-gulf-union-plan-stumbles-as-wary-leaders-seek-detail-idUSB RE84G0WN20120517\#yXXzFWO86KSvvlPV.97> [Accessed 30 March 2020].

Josselin, D. and Wallace, W. (eds.), 2001. Non-State Actors in World Politics. London: Palgrave Macmillan UK.

Kamel, L. (ed.), 2017. The Frailty of Authority. Borders, Non-State Actors and Power Vacuums in a Changing Middle East. Rome: Edizioni Nuova Cultura.

Al Khalifa, K., 2019. Interview. Interviewed by Vitaly Naumkin and Vasily Kuznetsov. Manama, 28 October 2019. Authors' archive.

Krastev, I. Sem' pervyh urokov global'nogo koronavirusnogo krizisa [First Seven Lessons of the Global Coronavirus Crisis]. Rossiya v globalnoi politike [online]. Available at: < globalaffairs.ru/articles/sem-urokov-koronakrizisa/> [Accessed 30 March 2020]

Lebedeva, M., 2016. Aktory $v$ mezhdunarodnyh otnosheniyah $i$ mirovoì politike [Actors of International Relations and World Politics] [online]. Available at: <russiancouncil.ru/analytics-and-comments/analytics/aktory-vmezhdunarodnykh-otnosheniyakh-i-mirovoy-politike/> [Accessed 30 March 2020]. 
Levitt, M., 2013. Hezbollah as a Criminal Organisation. [online]. Available at: $<$ www.washingtoninstitute.org/policy-analysis/view/hezbollah-as-a-criminalorganisation $>$ [Accessed 30 March 2020].

Ligon, S., Harms, M., Crowe, J., Lundmark, L., and Simi, P., 2014. The Islamic State of Iraq and the Levant: Branding, Leadership Culture and Lethal Attraction. Final Report prepared for the Department of Homeland Science and Technology Directorate's Office of University Programs. College Park, MD: START.

Ligon, G.S. and Logan, M.K., 2020. Antecedents of Organizational Sophistication in Violent Non-State Actors [online]. Available at: <nsiteam.com/social/wpcontent/uploads/2020/01/200110-Ligon-and-Logan-Slides.pdf $>$ [Accessed 30 March 2020].

Marrone, A., Muti, K., 2019. Policies and Tools for Dealing with Nonstate Actors [online]. Available at: <carnegieeurope.eu/2019/11/28/policies-and-tools-fordealing-with-nonstate-actors-pub-80441\#tableContents> [Accessed 30 March 2020].

McMillan, M.E., 2013. Fathers and Sons. The Rise and Fall of Political Dynasty in the Middle East. New York: Pallgrave Macmillan.

Menderhausen, H., 1969. Transnational Society vs. State Sovereignty. Kyklos, 22(2), pp.251-275.

Moloney, K. and Stone, D., 2019. Beyond the State: Global Policy and Transnational Administration. International Review of Public Policy, 1(1), pp.104-118.

Naumkin, V. and Kuznetsov, V., 2020. K voprosu o tipologizatsii negosularstvennyh aktorov na Blizhnem Vostoke [On the Issue of Classification of Non-State Actors in the Middle East]. Mirovaia ekonomika i mezhdunarodnye otnosheniia, 64 (6), pp.104-113. Available at: <https://ras.jes.su/meimo/ s013122270010280-9-1-en> [Accessed 23 November 2020].

Nye, J.S. and Keohane, R.O., 1971. Transnational Relations and World Politics: An Introduction. International Organization, 25(3), pp.329-349.

Pack, O., 2019. Kingdom of Militias. Libya's Second War of Post-Qadhafi Succession. [online]. Available at: <www.ispionline.it/sites/default/files/ pubblicazioni/ispi_analysis_libya_pack_may_2019_0.pdf> [Accessed 30 March 2020].

Panić, M., 1998. Transnational Corporations and the Nation State. In: KozulWright, R. and Rowthorn, R. (eds.), 1998. Transnational Corporations and the Global Economy. London: Palgrave Macmillan, pp.244-276. 
Radpey, L., 2016. Kurdish Regional Self-Rule Administration in Syria: A New Model of Statehood and Its Status in International Law Compared to the Kurdistan Regional Government (KRG) in Iraq. Japanese Journal of Political Science, 17 (3), pp. 468-488.

RF Ministry of Foreign Affairs, 2019. O Rossiyskoi Kontseptsii obespecheniya kollektivnoi bezopasnosti v zone Persidskogo zaliva [On the Russian Concept of Security in the Persian Gulf Region]. [online]. Available at: <www.mid.ru/ rossijskaa-koncepcia-kollektivnoj-bezopasnosti-v-zone-persidskogo-zaliva/-/ asset_publisher/2lVdNGBn6g2B/content/id/3733575> [Accessed 30 March 2020].

Rosenau, J.N. (ed.), 1969. Linkage Politics: Essays on the Convergence of National and Systems. New York: Free Press.

Al-Tamimi, A.J., 2017. From Jabhat al-Nusra to Hay'at Tahrir al-Sham: Evolution, Approach and Future. [online]. Available at: <www.kas.de/c/document_library/ get_file?uuid=8cfa4cdb-e337-820d-d0bd-4cd998f38612\&groupId=252038> [Accessed 30 March 2020].

Taylor, P., 1984. Nonstate Actors in International Politics: From Transregional to Substate Organizations. Boulder, Colorado - London: Westview Press.

Tilleli, E., 2003. Le mouvement citoyen de Kabylie [The Civil Movement in Kabylie]. Pouvoirs, 3(106), pp.149-162.

Tsygankov, P.A., 2013. Negosudarstvennye uchastniki mirovoī politiki [NonState Actors in World Politics]. Nauchno-analiticheskiy zhurnal Obozrevatel, 9(284), pp.257-265.

Ucko, D., 2008. Militias, Tribes and Insurgents: The Challenge of Political Reintegration in Iraq Conflict. Security \& Development [e-journal], 8(3), pp.341373. DOI:10.1080/14678800802358171.

Williams, P., 2008. Violent Non-State Actors and National and International Security. [online]. Available at: <www.files.ethz.ch/isn/93880/VNSAs.pdf> [Accessed 30 March 2020].

Wolfers, A., 1962. The Actors in World Politics. In: Wolfers, A. (ed.). Discord and Collaboration: Essays on International Politics. Baltimore, Md: Johns Hopkins Press.

Zvyagelskaya, I.D., 2019. Blizhnī Vostok i Tsentral'naya Aziya. Globalnye trendy $v$ regional'nom ispolnenii [The Middle East and Central Asia. Global Trends in Regional Manifestations]. Moscow: Aspekt Press. 